\title{
Factors influencing the welding process to generate the phenomenon of cut off fingers in photovoltaic modules
}

\section{Factores que influyen en el proceso de soldadura para generar el fenómeno de los dedos cortados en los módulos fotovoltaicos}

SALAZAR-PERALTA, Araceli†*, PICHARDO-SALAZAR, José Alfredo², PICHARDO-SALAZAR, Ulises $^{3}$ and CHÁVEZ, Rosa Hilda ${ }^{4}$

\begin{abstract}
${ }^{\text {I} T e c n o l o ́ g i c o ~ d e ~ E s t u d i o s ~ S u p e r i o r e s ~ d e ~ J o c o t i t l a ́ n, ~ C a r r e t e r a ~ T o l u c a ~ A t l a c o m u l c o ~ k m ~ 44.8, ~ E j i ́ d o ~ d e ~ S a n ~ J u a n ~ y ~ S a n ~ A g u s t i ́ n, ~}$ Jocotitlán, México

${ }^{2}$ Centro de Bachillerato Tecnológico Industrial y de Servicios No. 161, Exhacienda la Laguna S/N Barrio de Jesús $2 a$ Sección, San Pablo Autopan, Toluca. Estado de México

${ }^{3}$ Centro de Estudios Tecnológicos Industrial y de Servicios No. 23. Avenida, Del Parque s/n, 52000 Lerma de Villada, México. ${ }^{4}$ Instituto Nacional de Investigaciones Nucleares, Carretera México-Toluca s/n. La Marquesa, Ocoyoacac, 52750, México.
\end{abstract}

ID $1^{\text {st }}$ Author: Araceli, Salazar-Peralta / ORC ID: 0000-0001-5861-3748, Researcher ID Thomson: U-2933-2018, CVU CONACYT ID: 300357

ID $1^{\text {st }}$ Co-author: José Alfredo, Pichardo-Salazar / ORC ID: 0000-0002-8939-9921

ID $2{ }^{\text {nd }}$ Co-author: Ulises, Pichardo-Salazar / ORC ID: 0000-0002-3758-2038

ID $3^{\text {rd }}$ Co-author: Rosa Hilda, Chávez / ORC ID: 0000-0002-2460-3346

DOI: $10.35429 /$ JTIP.2021.12.5.9.16

Received March 30, 2021; Accepted June 30, 2021

\section{Abstract}

In the production process of photovoltaic modules, there are defects of bad welding, defects in the raw material, degradation by environmental factors, as well as bad handling of the material or lack of maintenance, affecting the quality of the product. The omission of control of the temperature in the welding process causes the defect called cut fingers, which consists of the rupture presented by the collectors of the cell. The present research focused on studying the factors that influence the welding process for the generation of cut fingers, emphasizing the temperature measurement during the welding process. The methodology used consisted of describing the materials involved in the welding process and monitoring the temperature in the welding machine, as well as the ambient temperature. Some cells without solder were found. The temperature variation in the welding heads ranged from -14.9 to $-121^{\circ} \mathrm{C}$. With this study it is concluded that the temperature of the welding heads should continue to be monitored, since the variation is out of specification, the $\mathrm{pH}$ of the fluss must be verified, and the periodicity of its distillation must be determined to purify it and be able to reuse it.

Photovoltaic module, Welding, Cut Fingers
Resumen

En el proceso de producción de módulos fotovoltaicos, se presentan defectos de mala soldadura, defectos en la materia prima, degradación por factores ambientales, así como mal manejo del material o falta de mantenimiento, afectando la calidad del producto. La falta de control de la temperatura en el proceso de soldadura ocasiona el defecto llamado dedos cortados, el cual consiste en la ruptura que presentan los colectores de la celda. La presente investigación se enfocó en estudiar, los factores que influyen en el proceso de soldadura para la generación de dedos cortados, enfatizando en la medición de la temperatura durante el proceso de soldadura. La metodología empleada consistió en describir los materiales que intervienen en el proceso de soldadura y el monitoreo de la temperatura en la máquina soldadora, así como la temperatura ambiente. Se encontraron algunas celdas sin soldadura. La variación de la temperatura en los cabezales de soldadora fue de -14.9 a $-121^{\circ} \mathrm{C}$. Con este estudio se concluye que se debe seguir monitoreando la temperatura de los cabezales de soldadura, ya que la variación está fuera de especificación, se debe verificar el $\mathrm{pH}$ del fluss, y determinar la periodicidad de la destilación de éste para purificarlo y poder reutilizarlo.

Módulo fotovoltaico. Soldadura, Dedos cortados

Citation: SALAZAR-PERALTA, Araceli, PICHARDO-SALAZAR, José Alfredo, PICHARDO-SALAZAR, Ulises and CHÁVEZ, Rosa Hilda. Factors influencing the welding process to generate the phenomenon of cut off fingers in photovoltaic modules. Journal of Technologies in Industrial Processes. 2021. 5-12: 9-16

\footnotetext{
* Author Correspondence (araceli.salazar@ tesjo.edu.mx)

$\dagger$ Researcher contributing as first author.
} 


\section{Introduction}

Within the production process of Photovoltaic Modules there are different problems which are reflected in the finished product, as well as in the useful life of the module. For some of them there are methods that allow to detect and correct during the process such as bad welding, broken cells, or defects in the raw material, but there are problems that can only be seen with the passage of time and the deterioration of the module [Ferrara (2011)].

The deterioration affects the efficiency produced by the module through environmental factors, due to poor handling or maintenance, or due to defects caused during the production process, among which we can mention the defect of severed fingers that consists of the ruptures that present the collectors of the cell. Fig. 1.

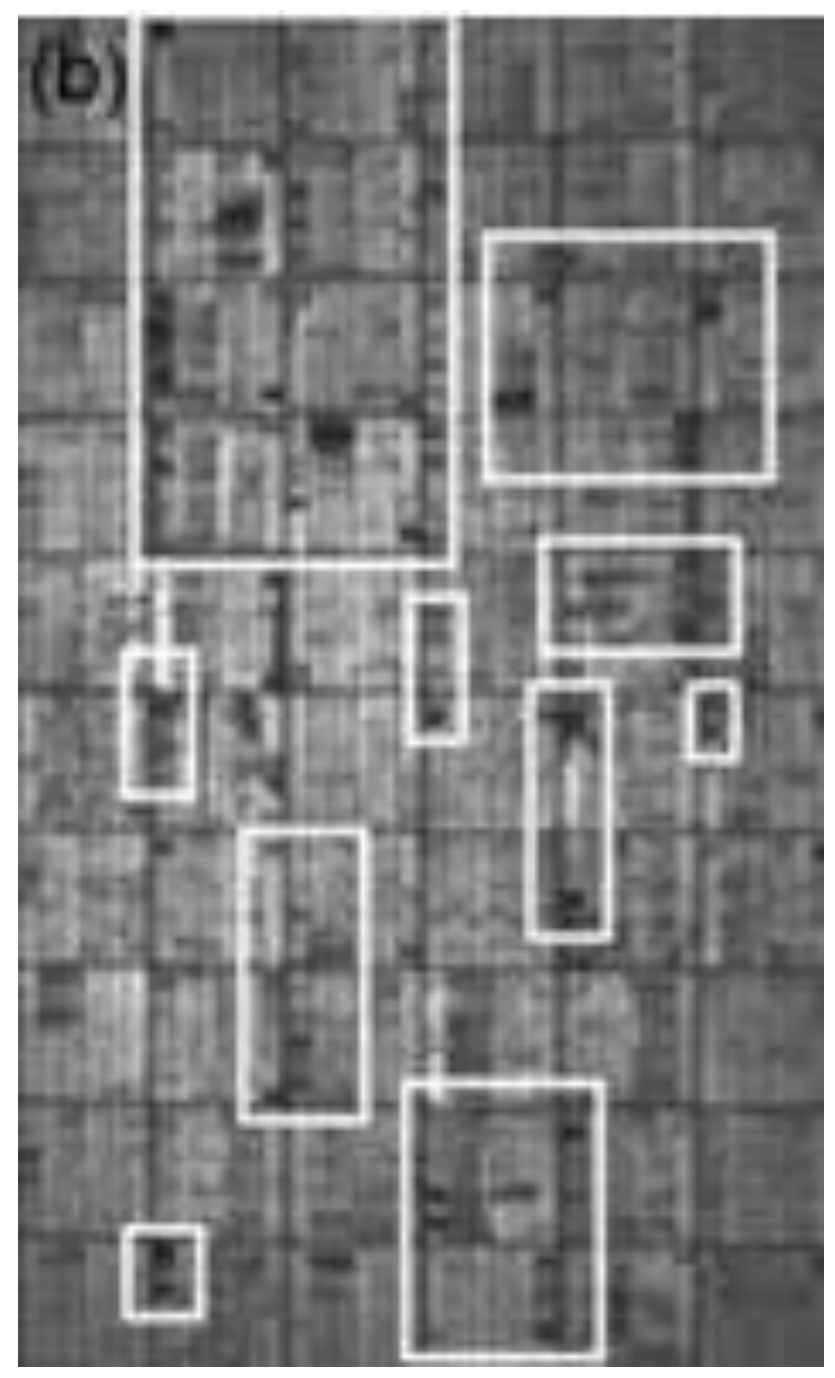

Figure 1 Cut Finger Collectors Own Elaboration

Photovoltaic solar energy is a renewable energy source and therefore inexhaustible, clean and can be harnessed in the same place where it is produced.
Energy sustainability in the future will be determined using renewable energies. As stated in the first principle of thermodynamics "energy is not created or destroyed", therefore, the use of energy from the sun to produce electricity or heat.

The photovoltaic solar cell is the device capable of capturing the energy of the sun and converting part of that energy into electricity, for this, a set of solar cells are interconnected with welding and encapsulated with Ethylene vinyl acetate, forming an essential part in the modules photovoltaics, which are the constructive element used for the implementation of solar photovoltaic systems.

The power, voltage and current of a photovoltaic module will depend on the number of associated solar cells and the working conditions, that is why a study of the variation and effect of temperature in solar cell welding machines was carried out, since a bad welding causes defects that affect the performance of photovoltaic modules.

The welding process is an important factor that can cause defects in the finished product, hence the importance of determining the variables that affect the process, as well as the appropriate characteristics of the material for the quality assurance of the process [Hacke P. (2010)].

\section{Welding process area}

This area consists of making chains of cells and an electrical interconnection with tape (ribbon) by means of contact welding technology see Figure 2.

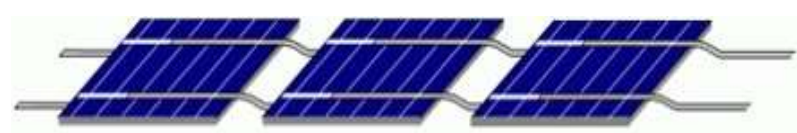

Figure 2 Cell string Own Elaboration

The stringer machine is an automated device in which the mechanism is a balance of temperatures of the solar cell by means of a preheating train to avoid a thermal shock in it when it comes into contact with a head with twelve pins. These pins make a type of spot welding because contact with the ribbon causes the heat to be distributed and joins with the cell buss. Figure 3.

SALAZAR-PERALTA, Araceli, PICHARDO-SALAZAR, José Alfredo, PICHARDO-SALAZAR, Ulises and CHÁVEZ, Rosa Hilda. Factors influencing the welding process to generate the phenomenon of cut off fingers in photovoltaic modules. Journal of Technologies in Industrial Processes. 2021 


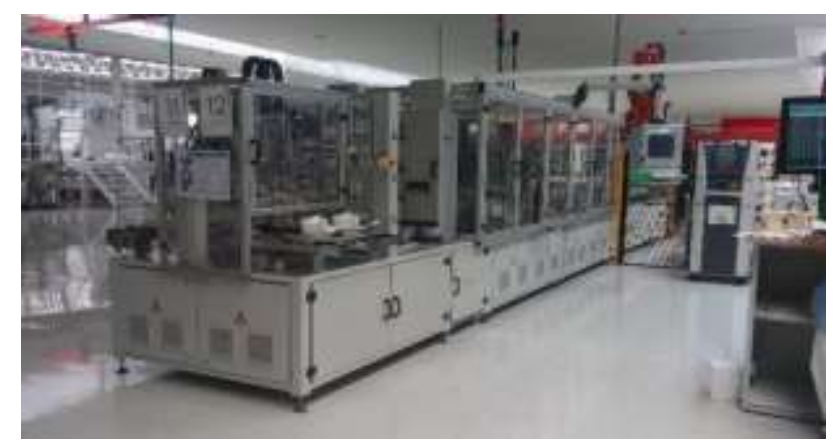

Figure 3 Stringer Brand Welding Machine Own Elaboration

The objective of this study was to determine the temperature variation in the heads of the Stringer machine, for the curbing of solar cells, as well as the factors that influence the welding process to generate the defect of cut off fingers.

\section{Methodology}

The procedure followed for the study was as follows:

\section{Study of the materials involved in the welding process}

1.1 Ribbon. The ribbon or interconnection tape is composed of tin, lead and silver, material that serves as welding to join cell to cell and also generate a circuit in series.

1.2 Flux. Flux or also called fundente is a chemical substance which is used in the welding process and its main functions are to isolate from air contact, dissolve and eliminate the oxides that can be formed and favor the "wetting" of the base material by the molten contribution metal, getting the contribution metal to flow and be distributed in the union.

\section{Factors that influence the welding process to generate the phenomenon of fingers cut in photovoltaic modules:}

\subsection{Coefficient of Thermal Expansion (CTE)}

It is well known that a solid expands when heated, or contracts when cooled. The problem that causes a greater thickness of the ribbon, is that it increases the Coefficient of thermal expansion (CTE), causing the silicon wafer to become curved and at the same time cause the rupture of the fingers of the cell (Figure 4).
For this very reason the choice of thickness and width of the welding material, is part of optimization of multiple parameters of cost and efficiency that supposes power losses, shading losses, network design, performance losses, reliability factors and the cost of welding.

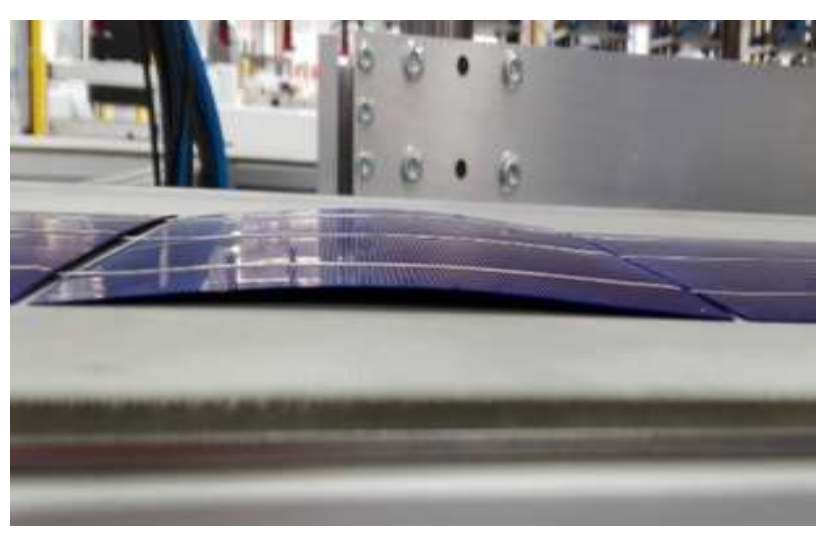

Figure 4 Wafer affected by variation of thermal coefficient

Own Elaboration

\subsection{Uniformity in the welding process}

The roughness problem is due to the discontinuity of the homogenization of the ribbon material and causes problems in manufacturing which are:

\subsection{Excess penetration}

This is determined in the stress test (pull test) and with the help of a microscope when detaching the ribbon from the cell, a detachment of the buss can be observed, and the silicon plate can break. (Figure 5.).

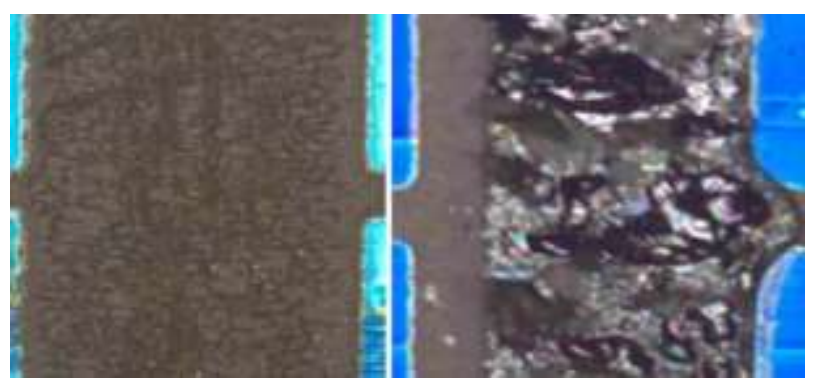

Figure 5 Penetration of Welding in the Buss of the Cell Own Elaboration

2.4 Lack of welding. Lack of welding is another defect caused by variations in temperature. Figure 6. 


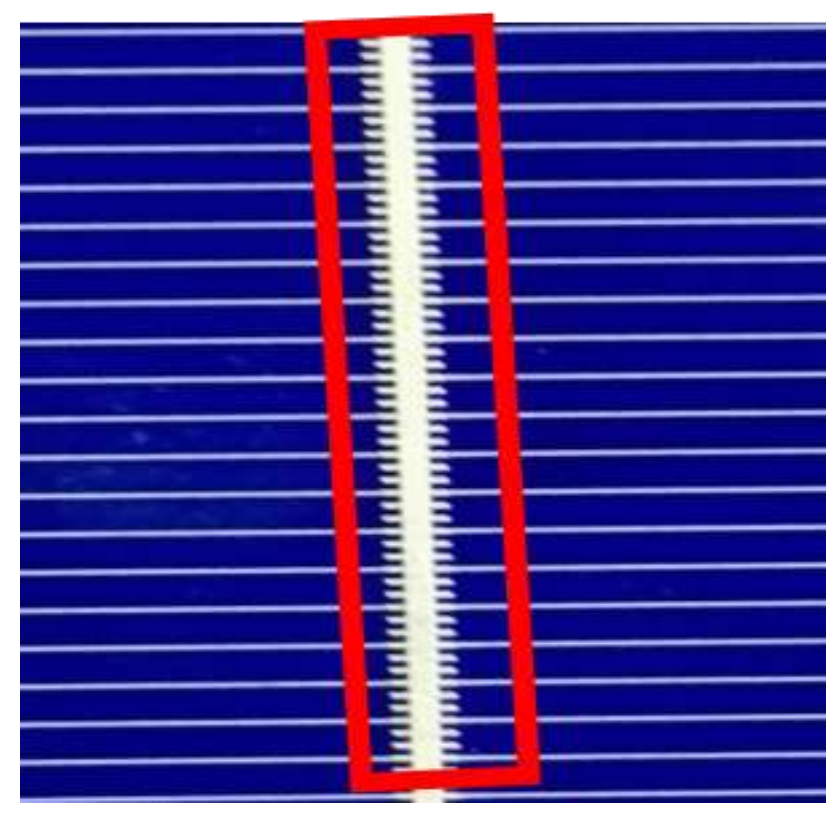

Figure 6 Cell with missing solder Own Elaboration

\subsection{Handling of the Stringer Brand Welding machine}

The handling of the Stringer welder comprises from the handling of materials to the control of the parameters required by the machine to work, since the main variable is the temperature is necessary a constant monitoring.

\section{Temperature measurement}

3.1 First, the ambient temperature of both the environment and the Stringer Machine was measured for 2 days. Table 1 .

\begin{tabular}{|l|r|r|}
\hline Hour & $\begin{array}{c}\text { Room } \\
\text { Temperature in } \\
\text { Plant }\end{array}$ & $\begin{array}{c}\text { Room Temperature } \\
\text { in Stringer Machine }\end{array}$ \\
\hline $9: 00$ & 20,6 & 29,4 \\
\hline $10: 00$ & 25,3 & 36,8 \\
\hline $11: 00$ & 25,6 & 39.3 \\
\hline $12: 00$ & 26,5 & 42 \\
\hline $16: 00$ & 28.9 & 34,5 \\
\hline $9: 00$ & 16,5 & 20 \\
\hline 10.00 & 22,3 & 37,6 \\
\hline 11.00 & 20,5 & 21,9 \\
\hline $12: 00$ & 22,6 & 37,8 \\
\hline $16: 00$ & 24,8 & 38,2 \\
\hline
\end{tabular}

Table 1 Room temperature inside and outside of Stringer Welder Machine Own Elaboration
3.2 Measurement of the temperature in the preheating areas of the stringer machine, 3 times a day (morning, noon and in the afternoon). Tables $(2,4,6)$.

The train of the heating zones is divided into ten zones, where the first four are pre-arranged raising the temperature of the cell and the ribbon, in zones five and six are the points where the joining process (welding) occurs, and the remaining points are another conditioning, in which the temperature gradually decreases to avoid a thermal shock, figure 7 illustrates the 10 areas mentioned. The measurement was made with an infrared thermometer brand Fluke 566.

\begin{tabular}{|l|r|r|}
\hline \multicolumn{1}{c}{$\begin{array}{c}\text { Heating } \\
\text { Zones }\end{array}$} & \multicolumn{1}{c}{$\begin{array}{c}\text { Specified } \\
\text { Temperature }\end{array}{ }^{\circ} \mathbf{C}$} & \multicolumn{1}{c|}{$\begin{array}{c}\text { Real } \\
\text { Temperature }{ }^{\circ} \mathbf{C}\end{array}$} \\
\hline 1 & 55 & 50,2 \\
\hline 2 & 70 & 69,4 \\
\hline 3 & 100 & 97,8 \\
\hline 4 & 120 & 110,6 \\
\hline 5 & 170 & 143,7 \\
\hline 6 & 170 & 118,7 \\
\hline 7 & 125 & 112,2 \\
\hline 8 & 105 & 92,6 \\
\hline 9 & 70 & 68,6 \\
\hline 10 & 60 & 57,9 \\
\hline
\end{tabular}

Table 2 Temperature readings on Stringer Machine at 9 a.m., with room temperature outside of the $19.7^{\circ} \mathrm{C}$ Stringer and within the $26^{\circ} \mathrm{C}$.Stringer

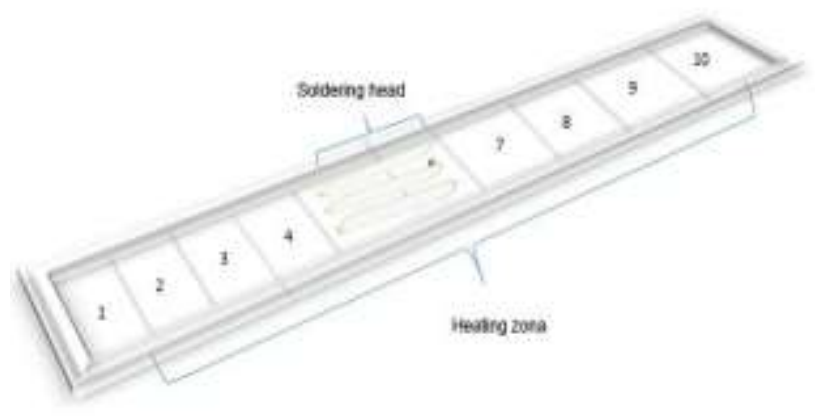

Figure 7 Scheme of preheating zones $(1,2,3,4)$ and of welding $(5,6)$ of Stringer Machine

Own Elaboration

3.3 The head has 12 pins, to make the temperature measurements, it was taken into consideration that each head has two resistors (zones 1,2), which was taken into consideration for the reading shot. Figure 8 , the zones $(1,2)$ are identified as soldering head in Figure 7. Tables 3, 4, 5 find the results of the measurement. 


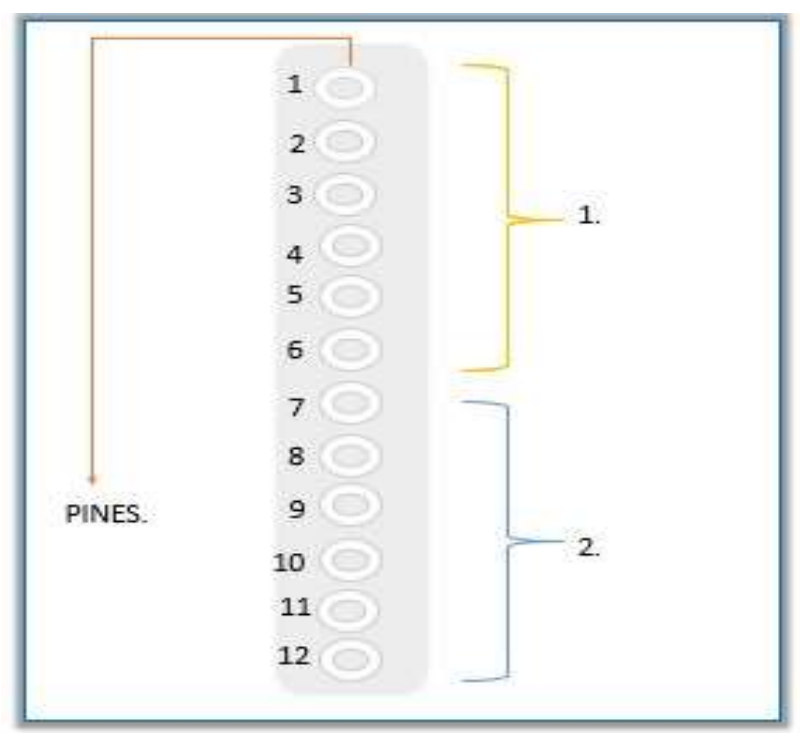

Figure 8. Stringer Welder Heads Diagram Own Elaboration

\begin{tabular}{|l|r|r|}
\hline \multicolumn{1}{|c|}{$\begin{array}{c}\text { Welding } \\
\text { Head }\end{array}$} & $\begin{array}{c}\text { Specified } \\
\text { Temperature }\end{array}$ & \multicolumn{2}{c|}{$\begin{array}{c}\text { Real } \\
\text { Temperature }\end{array}$} \\
\hline 1,1 & 245 & 120 \\
\hline 1,2 & 245 & 130,1 \\
\hline 2,1 & 245 & 128,3 \\
\hline 2,2 & 245 & 123,3 \\
\hline 3,1 & 245 & 128,2 \\
\hline 3,2 & 245 & 114,4 \\
\hline
\end{tabular}

Table 3 Temperature in Welding Heads at 9 a.m, with room temperature outside of the $19.7^{\circ} \mathrm{C}$, Stringer and within the $26^{\circ} \mathrm{C}$. Stringer

Own Elaboration

\begin{tabular}{|c|c|c|}
\hline $\begin{array}{l}\text { Heating } \\
\text { Zones }\end{array}$ & $\begin{array}{c}\text { Specified } \\
\text { Temperature }{ }^{\circ} \mathbf{C}\end{array}$ & $\begin{array}{c}\text { Real } \\
\text { Temperature }{ }^{\circ} \mathbf{C}\end{array}$ \\
\hline 1 & 55 & 54 \\
\hline 2 & 70 & 71 \\
\hline 3 & 100 & 96 \\
\hline 4 & 120 & 116 \\
\hline 5 & 170 & 138 \\
\hline 6 & 170 & 116 \\
\hline 7 & 125 & 114 \\
\hline 8 & 105 & 100 \\
\hline 9 & 70 & 78 \\
\hline 10 & 60 & 70 \\
\hline
\end{tabular}

Table 4 Temperature in Heating Zones. 12h, with room temperature outside the Stringer of $22.7^{\circ} \mathrm{C}$ and within $27.9^{\circ} \mathrm{C}$

Own Elaboration

\begin{tabular}{|l|r|r|}
\hline \multicolumn{1}{|c|}{$\begin{array}{c}\text { Welding } \\
\text { Head }\end{array}$} & $\begin{array}{c}\text { Specified } \\
\text { Temperature }\end{array}{ }^{\circ} \mathbf{C}$ & $\begin{array}{c}\text { Real } \\
\text { Temperature }{ }^{\circ} \mathbf{C}\end{array}$ \\
\hline 1,1 & 245 & 124 \\
\hline 1,2 & 245 & 135 \\
\hline 2,1 & 245 & 154 \\
\hline 2,2 & 245 & 149 \\
\hline 3,1 & 245 & 143 \\
\hline 3,2 & 245 & 137 \\
\hline
\end{tabular}

Table 5 Stringer Welding Heads Temperature at 12 hours, with room temperature outside the Stringer of $22.7^{\circ} \mathrm{C}$ and within $27.9^{\circ} \mathrm{C}$

Own Elaboration

ISSN 2523-6822

ECORFAN® ECORFAN® All rights reserved

\begin{tabular}{|c|c|c|}
\hline $\begin{array}{l}\text { Heating } \\
\text { Zones }\end{array}$ & $\begin{array}{c}\text { Specified } \\
\text { Temperature }{ }^{\circ} \mathrm{C}\end{array}$ & $\begin{array}{c}\text { Real } \\
\text { Temperature }{ }^{\circ} \mathbf{C}\end{array}$ \\
\hline 1 & 55 & 58 \\
\hline 2 & 70 & 72 \\
\hline 3 & 100 & 97 \\
\hline 4 & 120 & 113 \\
\hline 5 & 170 & 150 \\
\hline 6 & 170 & 133 \\
\hline 7 & 125 & 114 \\
\hline 8 & 105 & 99 \\
\hline 9 & 70 & 73 \\
\hline 10 & 60 & 66 \\
\hline
\end{tabular}

Table 6 Temperature in heating zones, 17 hours, with room temperature outside the Stringer of $23.5^{\circ} \mathrm{C}$ and within $29.3^{\circ} \mathrm{C}$

Own Elaboration

\begin{tabular}{|l|r|r|}
\multicolumn{1}{c}{$\begin{array}{c}\text { Welding } \\
\text { Head }\end{array}$} & \multicolumn{1}{c}{$\begin{array}{c}\text { Specified } \\
\text { Temperature }^{\circ} \mathbf{C}\end{array}$} & \multicolumn{1}{c|}{$\begin{array}{c}\text { Real } \\
\text { Temperature }\end{array}$} \\
\hline 1,1 & 245 & 245.2 \\
\hline 1,2 & 245 & 245 \\
\hline 2,1 & 245 & 245.4 \\
\hline 2,2 & 245 & 245 \\
\hline 3,1 & 245 & 245.6 \\
\hline 3,2 & 245 & 245.3 \\
\hline
\end{tabular}

Table 7 Stringer heads Temperature at 17 hours., with room temperature outside the Stringer of $23.5^{\circ} \mathrm{C}$ and within $29.3^{\circ}$

Own Elaboration

\section{Results}

As can be seen in Table 1. The ambient temperature ranged from $16.5^{\circ} \mathrm{C}$ to $28.9^{\circ} \mathrm{C}$. The ambient temperature on the Stringer machine ranged from $20^{\circ} \mathrm{C}$ to $42^{\circ} \mathrm{C}$. As can be noticed this temperature variation is due to the environmental changes that naturally occur during all the months of the year, which influences the heating zones, as well as the variation of the temperature of the heads in the welding areas of the Stringer machine. The temperature variation in the welding areas at 9 a.m. ranged from $-26.3^{\circ} \mathrm{C}$ to $-51.6^{\circ} \mathrm{C}$. Table 2 , Graph 1. 
Temperature in heating zones

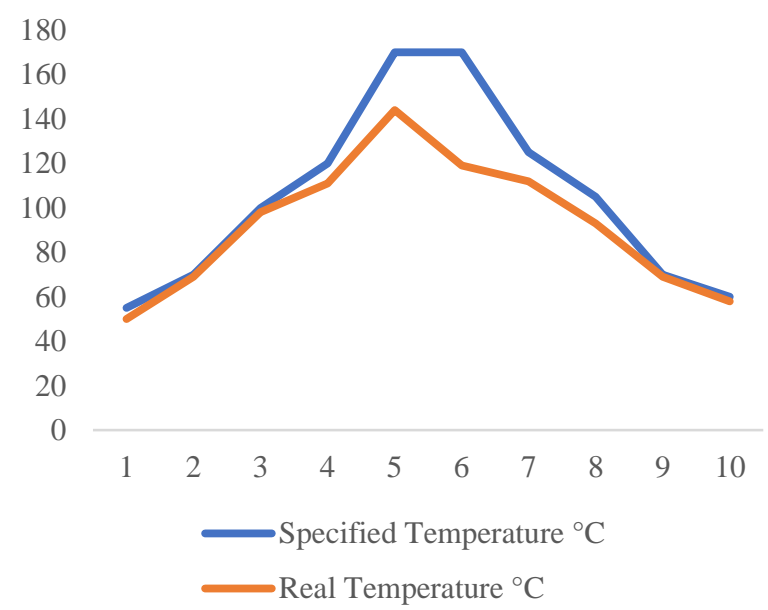

Graph 1 Temperature in heating zones at 9 o'clock Own Elaboration

The temperature variation in the Stringer welder heads at 9 a.m. ranged from $-114.9^{\circ} \mathrm{C}$ to $-130.6^{\circ} \mathrm{C}$ of the specified value. Table 3 . Figure 2.

\section{Temperature in Stringer welder heads}

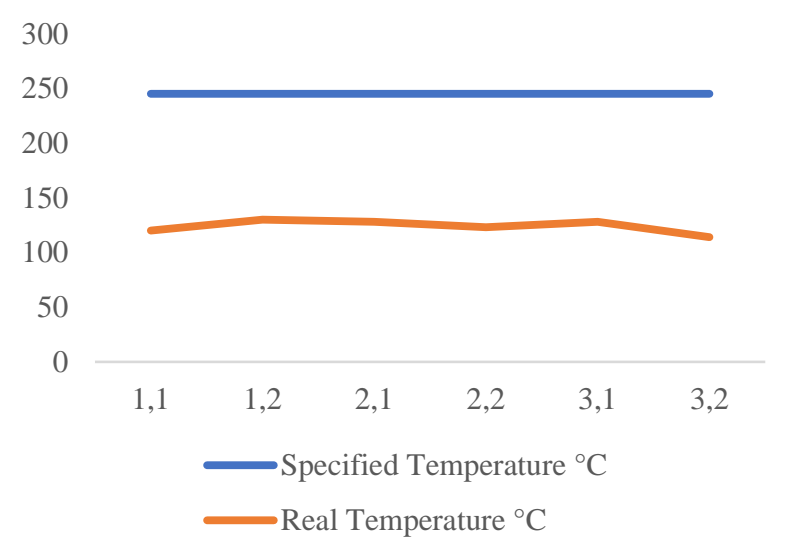

Graph 2 Temperature monitoring in Welder Heads at 9 a.m

Own Elaboration

Temperature variation in the welding heating zones at 12 hours ranged from $-32^{\circ} \mathrm{C}$ in zone 5 to $-54^{\circ} \mathrm{C}$ in zone 6 . With respect to the specified value. Table 4. Figure 3.

\section{Temperature in heating zones}

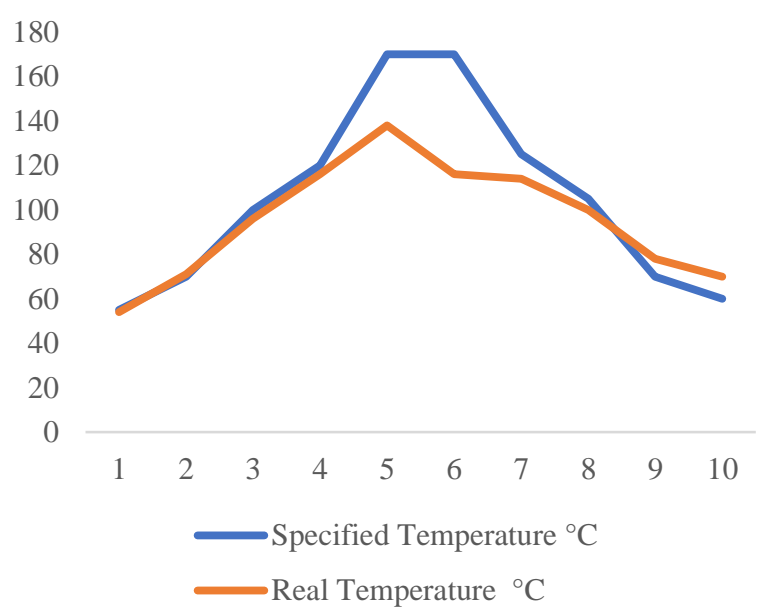

Graph 3 Temperature in heating zones at 12 hours Own Elaboration

Temperature variation in stringer weld heads at 12 o'clock ranged from $-91^{\circ} \mathrm{C}$ to $-121^{\circ} \mathrm{C}$ of the specified value. Table 5. Figure 4.

Temperature in Stringer welder heads

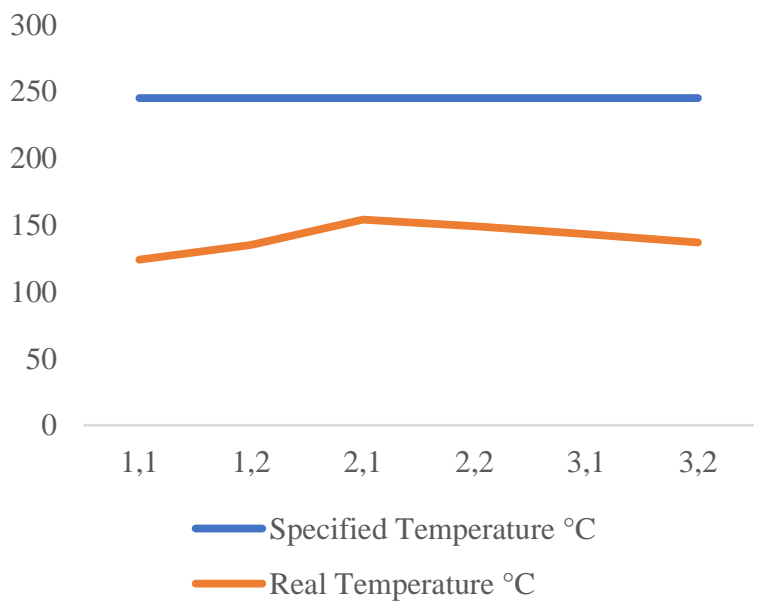

Graph 4 Temperature in Stringer Welder Heads. (12 hours)

Own Elaboration

Temperature variation in the welding heating zones at 5 p.m. ranged from $-20^{\circ} \mathrm{C}$ in zone 5 to $-36^{\circ} \mathrm{C}$ in zone 6 . With respect to the specified value. Table 6. Figure 5. 
Temperature in Heating Zones

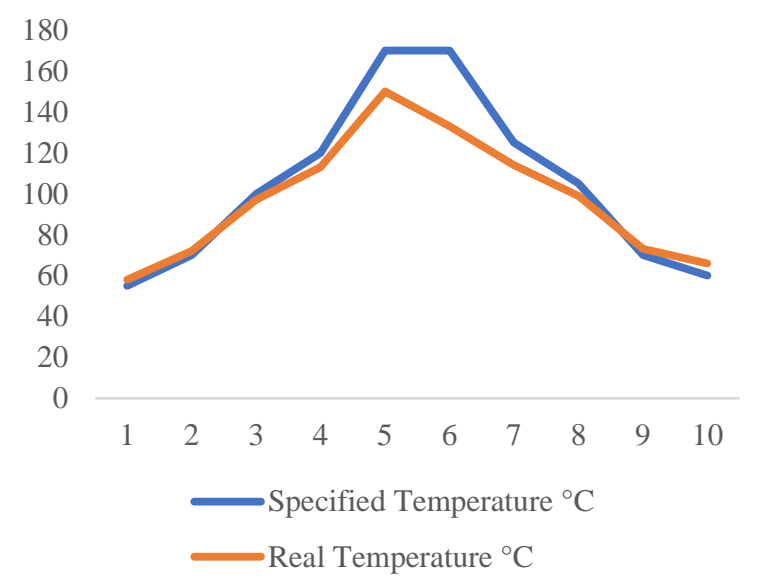

Graph 5 Temperature in Heating Zones. Monitoring at 17 hours

Own elaboration

The temperature variation in the Stringer welder heads at 5 p.m. ranged from $0^{\circ} \mathrm{C}$ to $+1.2^{\circ} \mathrm{C}$ of the specified value. Table 7. Figure 6 .

\section{Temperature in Stringer welder heads}

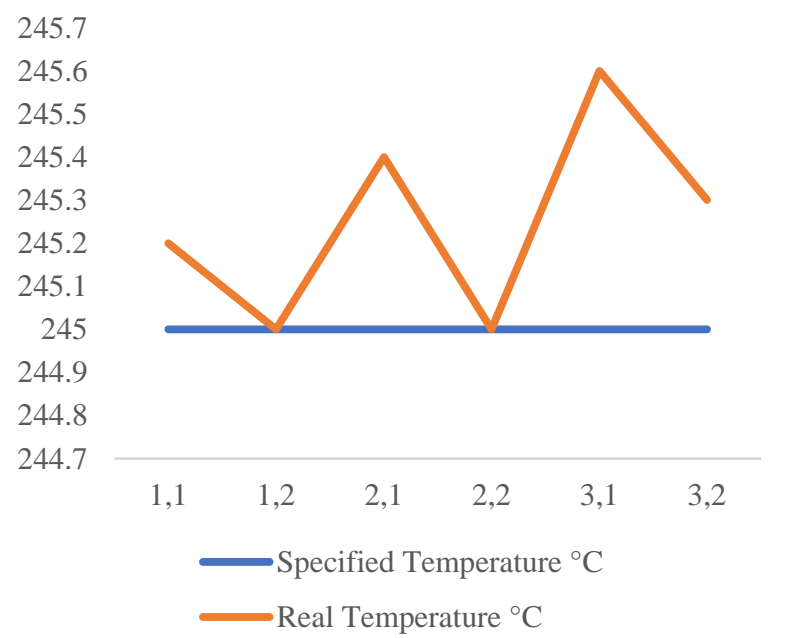

Graph 6 Temperature in Stringer Welder Heads. Data measured at 17 hours Own Elaboration

As you can see. In the morning when the ambient temperature is lower, the variation in the welding heads is greater. However, at 17 hours when the Stringer machine has worked 9 hours the temperature of the heads is within specification $+-10^{\circ} \mathrm{C}$. This indicates that the machine should remain without shutting down 24 hours, it is also advisable to have controlled ambient temperature conditions in the welding area, to reduce temperature variations, as they influence lack of welding in solar cells.

\section{Conclusions}

The ambient temperature outside the stringer, must be from 27 to $28^{\circ} \mathrm{C}$ and within it of $35-38$ ${ }^{\circ} \mathrm{C}$ so that the pins of the heads reach the established temperature and there is a range of \pm $10^{\circ} \mathrm{C}$, for winter seasons months of (NovemberFebruary), a heating equipment is needed within the work area, because if you do not have a certain system, the welding machine in the head area does not reaches the established temperature, causing failures in the solar cells, due to poor welding. It is recommended to continue monitoring the temperatures both ambient and in the heads of the Stringer welder, for quality assurance of the process.

\section{Acknowledgment}

To the Industry Academy Linking Center (CAI) of the Jocotitlán Higher Studies Technological Institute

\section{References}

A. Gabor, M. Ralli, S. Montminy, L. Alegria, C. Bordonaro, J. Woods, L. Felton, "Soldering induced damage to thin $\mathrm{Si}$ solar cells and detection of cracked cells in modules," Proceedings of the 21st EUPVSEC, Dresden, Germany, 2006, pp. 2042-2047.

A. Halm, V. Mihailetchi, G. Galbiati, L. Koduvelikulathu, R. Roescu, C. Comparotto, R. Kopecek, K. Peter, J. Libal, 'The Zebra cell concept - large area n-type interdigitated back contact solar cells and one-cell modules fabricated using standard industrial processing equipment," Proceedings of the 27th EUPVSEC, Frankfurt am Main, Germany, 2012, pp. 567-570.

A. Schneider, M. Pander, T. Korvenkangas, S. Aulehla, R. Harney, T. Horttana, "Cell to Module Loss Reduction and Module Reliability Enhancements by Solder Ribbon Optimization," Proceedings of the 29th EUPVSEC, Amsterdam, Netherlands, 2014, pp. 165-170.

Barrera, P. (2009). "Simulación y caracterización de celdas solares multijuntura y de silicio cristalino para aplicaciones espaciales." (Tesis de Doctorado). Universidad Nacional de General San Martin Comisión Nacional de Energía Atómica Instituto de Tecnología. República Argentina.

SALAZAR-PERALTA, Araceli, PICHARDO-SALAZAR, José Alfredo, PICHARDO-SALAZAR, Ulises and CHÁVEZ, Rosa Hilda. Factors influencing the welding process to generate the phenomenon of cut off fingers in photovoltaic modules. Journal of Technologies in Industrial Processes. 2021 
C. Ferrara,"Philip Why do PV Modules Fail?, in: Proceedings of the International Conference on Materials for Advanced Technologies, Singapore", Energy Procedia 15, 2011, 379387.

Cengel, Y., y Hernán, P. J. (2004). "Transferencia de calor". México: McGrawHill.

Duran, J. C., Bruno, C. J., y Bolzi, C. G. (2002). "Convenio de cooperación CONAE-CNEA: Desarrollo, fabricación y ensayo de paneles solares para misiones satelitales argentinas.' Profesional Independiente, 20(1), 0329-5184.

Fundamentos, dimensionado y aplicaciones de la energía solar fotovoltaica. Madrid : Ministerio de Ciencia y Tecnologia : Ciemat, 2004. M. Ibáñez Plana, J.R. Rosell Polo, J.I. Rosell Urrutia.

I. Kunze, S. Kajari-Schröder, X. Breitenmoser, B. Bjørneklett, "Quantifying the risk of power loss in PV modules due to micro cracks," Solar Energy Materials and Solar Cells 95, 2011, pp. 1131-1137.

Mimeur, R. (2021). Electromecánica de precisión. Edit. Reverte.

M. Sander, S. Dietrich, M. Pander, M. Ebert, M. Karraß, R. Lippmann, M. Broddack and D. Wald, "Influence of manufacturing processes and subsequent weathering on the occurrence of cell cracks in PV modules," Proceedings of the 28th EUPVSEC, Paris, France, 2013, pp. 3275-3279.

P. Hacke, K. Terwilliger, S. Glick, D. Turdell, N. Bosco, S. Johnston, S. Kurtz, "Test-toFailure of Crystalline Silicon Modules", in: Proceedings of 35th IEEE Photovoltaic Specialists Conference, Hawaii, 2010, pp. 248250.

R. Kahtri, S. Agarwal, I. Saha, S.K. Singh, B. Kumar, Study on Long Term Reliability of Photovoltaic Modules and Analysis of Power Degradation Using Accelerated Aging Tests and Electroluminescence Technique, in: proceedings of the 1st International Conference on Silicon Photovoltaics, Freiburg, Energy Procedia 8, 2011, 396-401.
S. Kajari-Schroder, I. Kunze, U. Eitner, M. K * ontges, Spatial and orientational " distribution of cracks in crystalline photovoltaic modules generated by mechanical load tests, Solar Energy Materials and Solar Cells 95 (2011) 3054-3059.

Yeisson Torres. (2014). La Soldadura. 27 de junio 2014, de blogspot Sitio web: http://lasoldaduradetodoslostiempos.blogspot. mx/2014/06/la-historia-delasoldadura_27.html. 